\title{
BUSINESS MICRO-LOCATION: FACTORS, PREFERENCES AND INDICATORS TO ASSESS THE INFLUENCE FACTORS
}

\author{
Cornel Ghita ${ }^{1}$, Cezar Scarlat ${ }^{1}$, José Freitas Santos ${ }^{2}$, Antonio Correia de Barros ${ }^{2}$ \\ ${ }^{1}$ Polytechnic University of Bucharest, Faculty of Entrepreneurship, Business Engineering and Management, Romania \\ ${ }^{2}$ Polytechnic Institute of Porto, Institute of Accounting and Administration of Porto, Portugal
}

Corresponding author:

Cornel Ghita

University "Politehnica" of Bucharest

Faculty of Entrepreneurship, Business Engineering and Management

313 Splaiul Independentei, Bucharest, Romania

phone: (+4021) 402-98-88

e-mail: cornel.ghita8@yahoo.com

Received: 24 January 2013

Accepted: 1 March 2013

\begin{abstract}
The paper presents a study on business micro-location behaviour as well as corresponding factors of influence, conducted in two metropolitan areas, Bucharest-Ilfov (Romania) and Greater Porto (Portugal). By business micro-location we refer to a specific site such as a building or facility, accommodating a business within a small, compact geographical area (e.g. metropolitan area). At this geographical scale, the macroeconomic layer factors were excluded, applicable when discern between regions or countries. The factors derived from location theory and previous empirical studies were surveyed, completing a cross-sectional analysis in order to find out the specific weights of the location factors and preferences, by region and by industry. Based on already established firms' feedback on location, the specific weights were granted by each industry to the main location factors, types of areas, and types of accommodation facilities. The authors also suggested a model to integrate these results into a Geographical Information System (GIS).
\end{abstract}

KEYWORDS

business micro-location, metropolitan areas, location factors, Bucharest-Ilfov, Greater Porto.

\section{Introduction}

The paper reports the findings of a bi-cultural empirical study, completed in 2012 in two distant regions of Europe, respectively Greater Porto (Portugal) and Bucharest-Ilfov (Romania). The purpose was to capture a location behaviour model based on the experience of existing enterprises, i.e. to find out the location factors, preferred area types, and facility types, as well as their specific weights by industry. The reason for selecting the two distant regions was the intention to build a relevant location model applicable to metropolitan areas, analyzing the differences between the study regions and generalizing location factors, area and facility types. Both study regions are medium-sized metropolitan agglomerations, with similar cultural background, population (2 million roughly), size, infrastructure. Though, dif- ferences might arise from their distinct evolutionary paths as well as due to the sea access of Grater Porto.

First, a set of hypothetic factors was derived from location theory and previous empirical studies. Then an adequate taxonomy of industries, factors, areas and facility types was built. The investigation was questionnaire-based - which was developed in two steps: pilot version tested on 108 answers, and the improved final version administered at a larger scale.

The research had a micro-location approach, zooming in at neighbourhood, street and building level. At this scale, the layer of macroeconomic factors that can influence the location decision (population income, education, labour terms and availability) was disabled. Considering the mobility within a metropolitan area - due to transportation networks and means - the macroeconomic layer factors were considered as applicable to macro-geographical scale 
only. The macroeconomic layer location factors are mandatory to be enabled when extending to a multiregion or multi-country space, to discern between different regions or countries.

Analyzing and weighting the reasons behind location behaviour of established enterprises, it was obtained a canvas of what enterprises in different industries look for in certain locations.

Eventually, a pattern to integrate this paper's findings into a Geographical Information System (GIS) is suggested, useful in the case of developing a software tool to support the location decisions.

\section{Theoretical framework}

Over time, the location theory experienced four major approaches: (neo) classical, behavioural, institutional, and evolutionary.

The parent of the location theory is considered the German economist von Thünen who has developed a still-standing theory of land use [1]: homogenous economic activities coagulate in concentric circles around the town centre (market). Depending on the maximum cost they afford to pay for land (rent, price) and the transportation cost of production to the market, they locate closer or farther from the town centre. This theory considers land as the main production factor and as such it is more relevant for the primary sector. However, it can be extended to other sectors, by analogy to other factors of production. In 1967, Alonso [2] has re-valued and applied the land use theory to the modern urban economy.

Under the same classical approach, Weber solved the location problem by optimizing the transportation cost [3], calculating the centre of gravity (weighted centroid) between the sources of raw materials and market, applicable in the secondary sector, especially in heavy manufacturing. Christaller and Lösch explained location problem by a set of hierarchy and sustainability principles of activities based on market potential (market areas) and economies of scale [4, 5]. Hotelling studied direct competition for space (i.e. business facilities) between production units in the same industry, revealing a clustering tendency [6]. Their successors have developed these theories into more complex and abstract models.

Amid explosive economic development of 1960s, scientific advances and rise of multinational companies, the (neo) classical models were challenged as being unable to explain the location behaviour of firms. Critics argued that firms were seen as "black boxes" whose internal mechanisms were not important. It was the time for the behavioural approach of the location theory, focusing on internal factors, limited information and the ability to use it [7], own perception of reality, preferences and uncertainty.

During the 1970s, by institutional approach, location factors were sought more deeply into the cultural values of society and related to the institutions and the other firms [8-10]. An important concept, although observed earlier by Marshall [11], is the formation of clusters.

The newest wave, since 1990s, is the evolutionary approach, which has its roots in evolutionary economics, which integrates the biology concepts of the evolutionist theory of Charles Darwin in economics. Thus, the concepts of individual variability, natural selection and heredity are similar in economic theory to diversifying/innovation, competition and path dependence [12].

In recent years, along with modern approaches behavioural, institutional and evolutionary, adapting to the new socio-economic framework, neoclassical approach has regained its strength by the newest of its streams, so-called "new economic geography" [13]. The benefits of modern computing opened the way for complex statistical and mathematical analysis, as well as for the development of more realistic models based on monopolistic competition, interaction between regions, and product diversification. In recent years, the law of increasing returns shapes the features of economic development [14].

\section{Methodology}

The taxonomy of the primary questionnairebased research was based on the findings of secondary research - i.e. previous empirical studies on business relocation and relocation behaviour, mostly performed in the Netherlands [15-17] and Romania [18]. It was not the authors' intention to make any comparison between Dutch and Romanian business environments, but to benefit from the research methodology and experience of a developed country. The concern of the Dutch research for business location is understandable, given that the Netherlands is the European country having the highest population density and urbanization. Thus, space became a scarce, extremely valuable resource.

In addition, the Dutch studies were considered as relevant for the study of metropolitan areas. These studies reported a generally valid set of location factors and preferences (for areas and facilities) and three internal variables that influence the location behaviour namely: industry, firm's stage of the growth cycle, and ownership of facilities. The latter two refer to already established enterprises (and not relevant for start-ups). 
Aiming at building micro-location matrices by industry, types of industrial facilities and urban areas, the questionnaire was developed considering a few issues.

(i) The first issue while developing the microlocation behaviour questionnaire was to cover all possible cases of location decision and the reasons behind it. The taxonomy of industries, factors, types of areas, and types of facilities was developed accordingly.

Depending on their direction and intensity of influencing the (re)location decision, three categories of reasons were identified:

- push reasons, i.e. the disadvantages of the current location;

- pull reasons, i.e. the advantages of a new location, that attracts the business toward it;

- keep reasons, i.e. the positive reasons (advantages of current location) or negative reasons (lock-in) to maintain the current location.

(ii) The second aspect was to find out if there is a different location behaviour concerning back-office and front-office activities. Back-office is defined as the place in which the company operates production, service, and storage, while front-office refers to the place where commercial and top-management activities take place.

(iii) By the end, the weights granted by respondents to the reasons where aggregated in the corresponding factors, from whom they derived, separately for back-office and front-office.

The questionnaire captures the spatial behaviour of firms based on three grids (list of items):

- location factors - features and benefits considered by firms when choosing their location;

- types of areas;

- types of facilities (smaller units than areas).

Each type of area and facility has its own functional features and endowments. The key location factors are highlighted separately, and specific factors aggregated by types of areas and spaces, because of their nature, homogeneity, and need to keep the number of factors reasonably low - in order to be easily understood and communicated to respondents.

In this survey, industry was considered the key independent variable influencing the micro-location behaviour.

The firm size (measured by number of employees) corresponds to the firm's stage of growth cycle in the Dutch studies. Although this variable can be also used for more in-depth analysis, it was excluded from the location matrices in order to keep the results simple and fit for GIS integration.
The space ownership (the third variable that appears in Dutch studies) was integrated into the main location factors set.

The research approach and process of developing the micro-location matrices is depicted in Fig. 1.

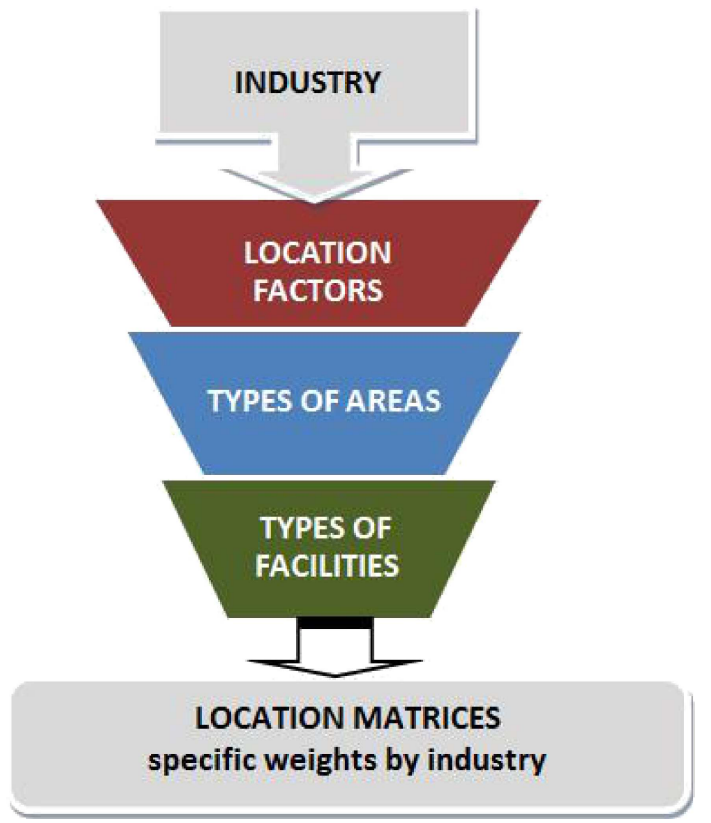

Fig. 1. Scheme for developing micro-location behaviour matrices.

\section{Industry panel}

Following the methodology and results of the Dutch studies and the Romanian sections of the National Classification of Economic Activities (NACE), harmonized with European Union classification, a panel of industries having homogeneous location behaviour was built. The NACE first division structure (sections) was used, in order to cover all economic activities. The NACE sections include homogeneous activities in terms of resources, finished products (markets), and production processes.

The industry panel included NACE first division only, as classification differences would have occurred between the two studied regions.

Some of the NACE sections were divided in subsections (e.g. trade or telecommunication) while other sections were aggregated (e.g. waste and energy, education and health). Only the NACE sections related to the private sector were selected (public administration was excluded). Consequently, the survey panel was composed of the following 17 industries:

1. Agriculture (including forestry and fisheries);

2. Mining and quarrying;

3. Manufacturing; 
4. Utilities (production and supply of energy, water, sanitation, waste collection);

5. Construction;

6. Retail;

7. Wholesale;

8. Transportation (including storage);

9. Hotels-restaurants;

10. Telecommunication;

11. IT-Software (Information Technology - software and services);

12. IT-Hardware (Information Technology - equipment restoration, maintenance, installation)

13. Media (mass media, including print);

14. Personal services (provided to individuals);

15. Professional services (rendered to enterprises);

16. Financial services (including insurance services);

17. Other services - not included in the previous categories (e.g. private education and health services).

\section{Micro-location factors}

Micro-location factors are the main advantages sought by firms when choosing their location. By the end of the primary research phase, a set of nine micro-location factors was selected as applicable to metropolitan areas (Table 1). Factors are refined by area and facility types, in a funnel style approach.

\section{Types of areas}

According to the land-use in metropolitan areas, fourteen types of commercial areas were identified as seen below:

1. Industrial area;

2. Wholesale park;

3. Mixed park (industrial and wholesale);
4. Science and technology park;

5. Business park (a compact area with modern office buildings);

6. Ring road;

7. Highway/main access route (town exits, railway station, airport);

8. Shopping center (compact commercial area: marketplace, mall etc.).

9. High street;

10. Residential - boulevard / main street;

11. Residential - secondary street;

12. Rural, including farming land;

13. Mobile unit (providing on-site);

14. Virtual (online/telephone orders).

The last two categories are pseudo-areas, but they are real business situations (especially in transports, utilities or retail).

\section{Types of facilities}

Similarly to the type of area, the type of facility summarizes some location factors derived from functional features or image of the site. At this level, the following nine facility categories were identified:

1. Open space / uncovered;

2. Industrial building;

3. Warehouse;

4. Technical facility (hosts special technical equipment: thermal energy station, cleaning station, depot etc.).

5. Office building (compact office buildings, not just a remote office in another type of facility, such as a billing office in a warehouse);

6. Commercial space - individual (street);

7. Commercial gallery inside a shopping center;

8. Villa;

9. Apartment/house.

Table 1

Correspondence between derived location factors and theoretical concepts.

\begin{tabular}{l|l}
\hline Location factor derived & Theoretical concept \\
\hline 1. Large space availability & Growth and life cycle \\
\hline 2. Suitability of utilities/services; endowments & Firm internal factors (product/service features, production processes) \\
\hline 3. Customer accessibility & Commuting (transportation) cost \\
\hline 4. Number of potential visitors & Market areas, sustainability \\
\hline 5. Supplier accessibility & Transportation cost optimization, linkages \\
\hline 6. Affordable rent/price for space & Bid-rent, land use, central business district \\
\hline 7. Representativeness of the area for the business & Agglomeration economies, positive externalities, image \\
\hline 8. Low competition level & Profit optimization, market area \\
\hline 9. Ownership of the current premises & $\begin{array}{l}\text { Capital inertia, dynamism within industry (technological, demand } \\
\text { changes etc.) }\end{array}$ \\
\hline
\end{tabular}




\section{The questionnaire}

Questionnaire flow is driven in the following sequence:

1. General information about the company: head office location, industry, size (number of employees), start-up year, respondent's position in the company;

2. Description of the current location - for both backoffice and front-office - including address, ownership type, area, and building type;

3. Prior location change: if and when it occurred, relocation object (back-office only, front-office only or both), motives (open answer);

4. Propensity to relocate - described by four possible cases, applicable both to operational unit and front-office:

a. Satisfied with the current location; not willing to move;

b. Unsatisfied and willing to move;

c. Unsatisfied but unable to move;

d. Cannot answer ("I don't know").

Location factors were assembled in three sets depending on the relocation propensity $(4-\mathrm{a}$, b, c), in order to reveal positive keep factors, push/pull factors and negative (lock-in) keep factors. Consequently, this part of the questionnaire (4) was structured in three sections, corresponding to the possible cases in relation to the propensity to move, one of them having two sub-cases, as follows:
- a section - case, satisfied by current location and unwilling to move, for the positive keep reasons;

- b section - case, unsatisfied and willing to move, with two sub-sections:

- b-push sub-case (reasons for not being happy with the current location, so-called push reasons);

- b-pull sub-case (expected improvements due to the new location, so-called pull reasons);

- c section - case, unsatisfied but unable to move, corresponding to negative keep (lock-in, inertia) reasons.

In each list an open answer option ("Other which?") is offered to respondents.

The representativeness of the spatial and industry sample is observed.

Table 2 displays a perspective of the factors spread over the case sections - and their correspondence. The first nine reasons (i.e. exactly the location factors) were selected as they have correspondents in more than one section; they are also applicable to start-ups; the last four reasons $(10 \ldots 13)$ are associated only to established businesses.

There were four types of respondents, according to their position within the company: enterprise owner, top-manager, middle-manager and employee. As level of information and involvement in the process of decision making is higher for the upper levels, the respondents' opinions are weighted (1.75 points to owner, ..., 1 point to employee).

Table 2

Correspondence between derived location cases reasons.

\begin{tabular}{|c|c|c|c|c|}
\hline No & $a$ reasons (positive keep) & $b$-push reasons & $b$-pull reasons & $c$ reasons (negative keep) \\
\hline 1 & Large space availability & Not enough space & Larger space & $\mathrm{n} / \mathrm{a}$ \\
\hline 2 & Suitability of utilities/services & $\begin{array}{l}\text { Utilities/services are not } \\
\text { suitable }\end{array}$ & Better utilities/services & $\mathrm{n} / \mathrm{a}$ \\
\hline 3 & Customer accessibility & $\begin{array}{l}\text { Difficult customer accessi- } \\
\text { bility }\end{array}$ & $\begin{array}{l}\text { Better customer accessibili- } \\
\text { ty }\end{array}$ & $\mathrm{n} / \mathrm{a}$ \\
\hline 4 & Potential visitors & $\mathrm{n} / \mathrm{a}$ & Potential visitors & $\mathrm{n} / \mathrm{a}$ \\
\hline 5 & Supplier accessibility & $\begin{array}{l}\text { Difficult supplier accessi- } \\
\text { bility }\end{array}$ & Better supplier accessibility & $\mathrm{n} / \mathrm{a}$ \\
\hline 6 & Affordable rent & High rent & Affordable rent & $\begin{array}{l}\text { Lower operational costs } \\
\text { (rent included) }\end{array}$ \\
\hline 7 & $\begin{array}{l}\text { Representativeness of the area } \\
\text { for the business }\end{array}$ & $\mathrm{n} / \mathrm{a}$ & $\begin{array}{l}\text { Representativeness of the } \\
\text { area for our type of business }\end{array}$ & $\mathrm{n} / \mathrm{a}$ \\
\hline 8 & Low competition level & High competition level & Lower competition level & $\mathrm{n} / \mathrm{a}$ \\
\hline 9 & $\begin{array}{l}\text { Ownership of the current } \\
\text { premises }\end{array}$ & $\begin{array}{l}\text { Want to buy/build on own } \\
\text { premises }\end{array}$ & Ownership of the facility & $\begin{array}{l}\text { Ownership of the current } \\
\text { premises }\end{array}$ \\
\hline 10 & $\mathrm{n} / \mathrm{a}$ & Firm reorganization & $\mathrm{n} / \mathrm{a}$ & $\mathrm{n} / \mathrm{a}$ \\
\hline 11 & $\mathrm{n} / \mathrm{a}$ & Legal restrictions imposed & $\mathrm{n} / \mathrm{a}$ & $\mathrm{n} / \mathrm{a}$ \\
\hline 12 & $\mathrm{n} / \mathrm{a}$ & $\mathrm{n} / \mathrm{a}$ & $\mathrm{n} / \mathrm{a}$ & High relocation costs \\
\hline 13 & $\mathrm{n} / \mathrm{a}$ & $\mathrm{n} / \mathrm{a}$ & $\mathrm{n} / \mathrm{a}$ & $\begin{array}{l}\text { Possible loss of key em- } \\
\text { ployees }\end{array}$ \\
\hline
\end{tabular}


The mathematical model of the location factors matrix weighted by industry, for the back-office, is defined as matrix $P_{B O}$ in (1) and (2).

$$
\begin{gathered}
P_{B O}=\left(p_{i j}\right), \\
p_{i j}=\frac{S_{B O i j}}{\sum_{j=1}^{9} S_{B O i j}},
\end{gathered}
$$

where

$$
\begin{gathered}
i=\overline{1,17} \text { (17 industries), } \\
j=\overline{1,9} \text { (9 factors), }
\end{gathered}
$$

$S_{B O i j}$ is the sum of points credited by industry $i$ to the factor $j$ for back-office, calculated as in (3), while $\sum_{j=1}^{9} S_{B O i j}$ is the sum of points awarded by the industry $i$ to all factors.

$$
S_{B O i j}=a_{B O i j}+b_{p u s h} h_{B i j}+b_{p u l l} \text { BOij }+c_{B O i j},
$$

where $a_{B O i j}$ is the sum of points granted in the reasons' section $a$ by the industry $i$ to the factor $j$ for back-office; bpush ${ }_{B O i j}$ is the sum of points granted in the reasons' section $b-$ push by the industry $i$ to the factor $j$ for back-office; bpull $B$ Bij is the sum of points granted in the reasons' section $b-$ pull by the industry $i$ to the factor $j$ for back-office; $c_{B O i j}$ is the sum of points granted in the reasons' section $c$ by the industry $i$ to the factor $j$ for back-office.

Sections are those shown in Table 2.

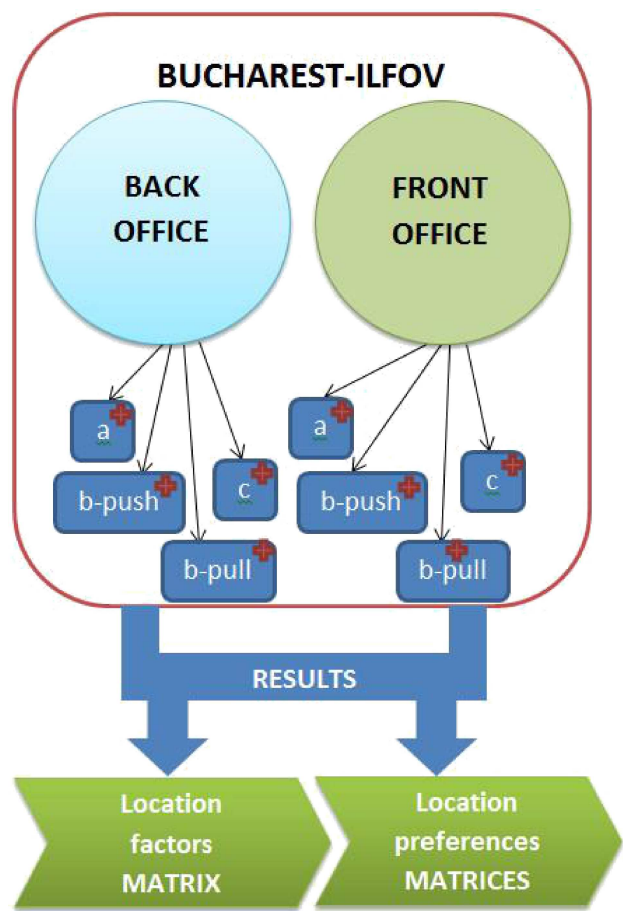

Fig. 2. Calculations flow towards results.

The same model was developed for the front-office case.
Similar calculations, separately for back-office and front-office were undertaken for the matrices of preferences (types of areas and types of facilities):

- by replacing factors with 14 types of areas $(j=\overline{1,14})$,

- by replacing factors with 9 types of facilities $(j=\overline{1,9})$.

A visual representation of calculations and the logical flow towards results exemplified for Bucharest-Ilfov region is shown in Fig. 2.

The same calculations were completed for Greater Porto as well.

\section{Results and discussion}

A total of 388 valid questionnaires were collected, namely 186 from Greater Porto and 202 from Bucharest-Ilfov.

The results are the location matrices weighted by industry. Actually, there is not just one matrix, but a number of six distinct matrices. There are two matrices (one for back-office and one for front-office) for each category (location factors, types of areas and types of facilities).

Previous studies or common economic sense might provide some hints about micro-location behaviour. Nevertheless, own results provide more than hints. They mathematically quantify the location behaviour, granting specific weights by industry and region. Furthermore, the sets of results from Bucharest-Ilfov and Greater Porto that can be compared or used in further studies.

Figures can be analysed in different ways. Herein, the results are presented with a focus on BucharestIlfov region, that suits this research plan, but there is also a corresponding side for Greater Porto metropolitan area.

The matrix of micro-location factors in Bucharest-Ilfov region is shown in Table 3 (backoffice), and Table 4 (front-office).

In case of some industries high biases towards certain factors could be observed (e.g. agriculture, mining and quarrying, utilities supply, media industry, and transportation), while, in case of others, a more balanced distribution of weights was reported (e.g. manufacturing, wholesale, retail, hotels-restaurants).

The bottom row (total) shows the overall weight of each factor for the entire industry panel. Thus, large space availability, suitability of utilities / services, and customer accessibility factors display the highest importance.

Conversely, number of potential visitors, low competition level, supplier accessibility, and representativeness of the area for the business prove as weak micro-location factors.

Volume $4 \bullet$ Number $2 \bullet$ June 2013 
Table 3

The matrix of micro-location factors for back-office (Bucharest-Ilfov) [weights \%].

\begin{tabular}{|c|c|c|c|c|c|c|c|c|c|c|}
\hline \multirow[b]{2}{*}{ Industry } & \multicolumn{10}{|c|}{ Micro-location factor } \\
\hline & 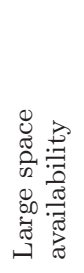 & 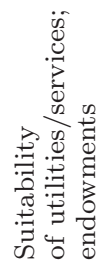 & 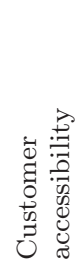 & 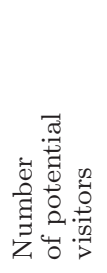 & 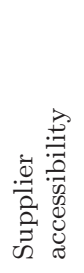 & 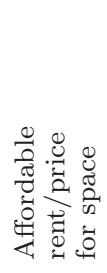 & 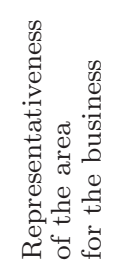 & 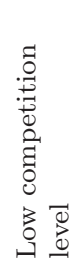 & 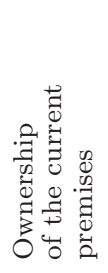 & 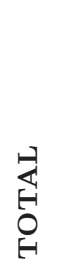 \\
\hline Agriculture & 30 & 22 & 0 & 0 & 0 & 13 & 13 & 0 & 22 & 100 \\
\hline Mining and quarrying & 41 & 23 & 0 & 0 & 12 & 0 & 12 & 0 & 12 & 100 \\
\hline Manufacturing & 18 & 12 & 15 & 2 & 16 & 4 & 8 & 7 & 18 & 100 \\
\hline Utilities & 20 & 15 & 15 & 4 & 20 & 0 & 6 & 0 & 20 & 100 \\
\hline Construction & 25 & 18 & 14 & 0 & 8 & 12 & 2 & 2 & 19 & 100 \\
\hline Retail & 15 & 15 & 14 & 8 & 10 & 9 & 8 & 4 & 17 & 100 \\
\hline Wholesale & 14 & 20 & 12 & 2 & 14 & 6 & 8 & 4 & 20 & 100 \\
\hline Transportation & 33 & 7 & 11 & 0 & 12 & 6 & 7 & 6 & 18 & 100 \\
\hline Hotels-restaurants & 15 & 16 & 12 & 2 & 10 & 5 & 12 & 8 & 20 & 100 \\
\hline Telecommunications & 29 & 14 & 10 & 2 & 6 & 12 & 10 & 6 & 11 & 100 \\
\hline IT-Software & 30 & 19 & 16 & 0 & 6 & 11 & 9 & 0 & 9 & 100 \\
\hline IT-Hardware & 27 & 14 & 17 & 5 & 5 & 9 & 5 & 9 & 9 & 100 \\
\hline Media & 29 & 23 & 23 & 0 & 0 & 19 & 6 & 0 & 0 & 100 \\
\hline Personal services & 21 & 21 & 14 & 7 & 11 & 12 & 7 & 0 & 7 & 100 \\
\hline Professional services & 19 & 6 & 16 & 5 & 8 & 28 & 4 & 4 & 10 & 100 \\
\hline Financial & 30 & 12 & 14 & 2 & 0 & 16 & 14 & 6 & 6 & 100 \\
\hline Other services & 28 & 12 & 15 & 1 & 8 & 13 & 10 & 4 & 9 & 100 \\
\hline TOTAL & 25 & 16 & 13 & 2 & 9 & 10 & 8 & 4 & 13 & 100 \\
\hline
\end{tabular}

Table 4

Matrix of the micro-location factors (front-office) - in Bucharest-Ilfov region [weights \%].

\begin{tabular}{|c|c|c|c|c|c|c|c|c|c|c|}
\hline \multirow[b]{2}{*}{ Industry } & \multicolumn{10}{|c|}{ Micro-location factor } \\
\hline & 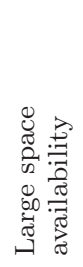 & 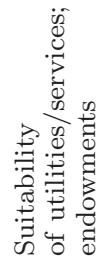 & 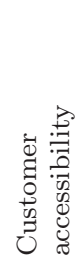 & 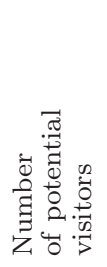 & 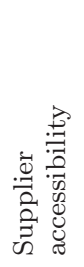 & 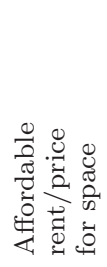 & 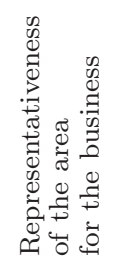 & $\begin{array}{l}0 \\
.0 \\
0 \\
0 \\
0 \\
0 \\
0 \\
0 \\
0 \\
0.0 \\
0.0 \\
0.0\end{array}$ & 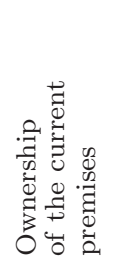 & 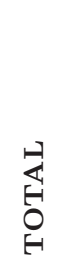 \\
\hline Agriculture & 46 & 14 & 0 & 0 & 0 & 26 & 14 & 0 & 0 & 100 \\
\hline Mining and quarrying & 45 & 37 & 18 & 0 & 0 & 0 & 0 & 0 & 0 & 100 \\
\hline Manufacturing & 21 & 11 & 15 & 2 & 16 & 6 & 7 & 6 & 16 & 100 \\
\hline Utilities & 17 & 14 & 21 & 4 & 17 & 4 & 6 & 0 & 17 & 100 \\
\hline Construction & 28 & 15 & 13 & 0 & 6 & 15 & 3 & 3 & 17 & 100 \\
\hline Retail & 13 & 13 & 17 & 9 & 9 & 10 & 7 & 9 & 13 & 100 \\
\hline Wholesale & 20 & 9 & 12 & 9 & 7 & 14 & 5 & 7 & 17 & 100 \\
\hline Transportation & 29 & 16 & 7 & 0 & 9 & 0 & 9 & 0 & 30 & 100 \\
\hline Hotels-restaurants & 15 & 16 & 15 & 3 & 9 & 8 & 13 & 8 & 13 & 100 \\
\hline Telecommunications & 22 & 17 & 14 & 3 & 6 & 15 & 7 & 3 & 13 & 100 \\
\hline IT-Software & 28 & 18 & 17 & 0 & 7 & 13 & 10 & 0 & 7 & 100 \\
\hline IT-Hardware & 22 & 18 & 22 & 5 & 9 & 9 & 5 & 5 & 5 & 100 \\
\hline Media & 24 & 19 & 24 & 0 & 0 & 11 & 16 & 0 & 6 & 100 \\
\hline Personal services & 25 & 19 & 19 & 9 & 5 & 9 & 9 & 0 & 5 & 100 \\
\hline Professional services & 23 & 7 & 13 & 3 & 7 & 33 & 3 & 6 & 5 & 100 \\
\hline Financial & 27 & 10 & 18 & 4 & 2 & 16 & 13 & 4 & 6 & 100 \\
\hline Other services & 20 & 13 & 17 & 5 & 6 & 17 & 8 & 6 & 8 & 100 \\
\hline TOTAL & 25 & 16 & 15 & 4 & 7 & 12 & 8 & 3 & 10 & 100 \\
\hline
\end{tabular}


Number of potential visitors factor shows a surprisingly low weight, even in case of well-known sensitive industries (such as retail, hotels-restaurants and personal services). A possible explanation is that respondents did not make a difference between customer accessibility and potential visitors, granting almost all credits to the former.

Actually, by customer accessibility it is intended to assess the available infrastructure (in terms of roads, means of transportation etc.) enabling customers to have an easy access to the business location, while potential visitors means the intensity and frequency of people passing by, such as road and footfall traffic. For this reason, it is suggested - for GIS integration purpose - to merge the two accessibility factors (customers and suppliers), into one simple factor named accessibility, avoiding strong words that attract respondents such as "customers".

Other notable findings are the differences and similarities between the two study regions, presented in Table 5 (for both back-office and front-office), which were calculated by subtracting the weights reported in Bucharest-Ilfov out of the weights in Greater Porto, industry by industry. The significant differences $(\geq 10 \%)$ are highlighted in bold.

Table 5

Matrix of micro-location factors' differences (Porto minus Bucharest) [weights \%].

\begin{tabular}{|c|c|c|c|c|c|c|c|c|c|c|c|}
\hline \multirow[b]{2}{*}{ Industry } & \multirow[b]{2}{*}{ Unit } & \multicolumn{10}{|c|}{ Location factor } \\
\hline & & 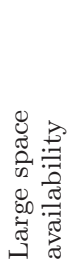 & 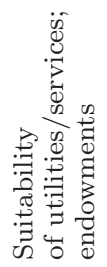 & 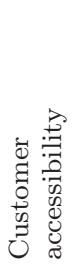 & 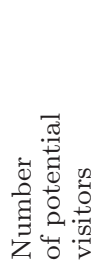 & 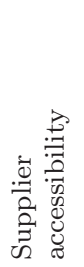 & 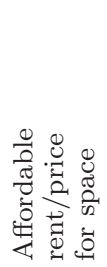 & 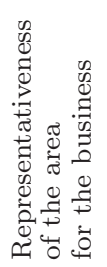 & 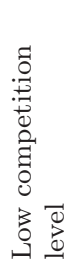 & 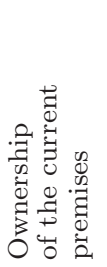 & $\begin{array}{l}\text { 嵌 } \\
0 \\
0 \\
H\end{array}$ \\
\hline Agriculture & \multirow{18}{*}{ 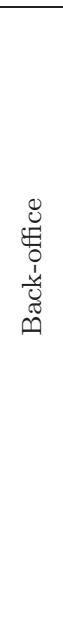 } & $\mathrm{n} / \mathrm{a}$ & $\mathrm{n} / \mathrm{a}$ & $\mathrm{n} / \mathrm{a}$ & $\mathrm{n} / \mathrm{a}$ & $\mathrm{n} / \mathrm{a}$ & $\mathrm{n} / \mathrm{a}$ & $\mathrm{n} / \mathrm{a}$ & $\mathrm{n} / \mathrm{a}$ & $\mathrm{n} / \mathrm{a}$ & 100 \\
\hline Mining and quarrying & & $\mathrm{n} / \mathrm{a}$ & $\mathrm{n} / \mathrm{a}$ & $\mathrm{n} / \mathrm{a}$ & $\mathrm{n} / \mathrm{a}$ & $\mathrm{n} / \mathrm{a}$ & $\mathrm{n} / \mathrm{a}$ & $\mathrm{n} / \mathrm{a}$ & $\mathrm{n} / \mathrm{a}$ & $\mathrm{n} / \mathrm{a}$ & 100 \\
\hline Manufacturing & & 7 & -4 & 3 & 1 & 0 & 1 & -4 & -3 & -2 & 100 \\
\hline Utilities & & -10 & 17 & 17 & -2 & -10 & 0 & -3 & 0 & -10 & 100 \\
\hline Construction & & 18 & -9 & -7 & 0 & 16 & -6 & -1 & -1 & -9 & 100 \\
\hline Retail & & 0 & -4 & 6 & 5 & 2 & -1 & -3 & 0 & -5 & 100 \\
\hline Wholesale & & 2 & -10 & 10 & 2 & 1 & 5 & -3 & -2 & -5 & 100 \\
\hline Transportation & & 6 & -3 & 4 & 9 & 3 & -3 & -3 & -3 & -9 & 100 \\
\hline Hotels-restaurants & & 0 & 1 & 5 & 8 & -1 & 0 & -1 & -4 & -8 & 100 \\
\hline Telecommunications & & 2 & -8 & 6 & -1 & 8 & 0 & 1 & -3 & -5 & 100 \\
\hline IT-Software & & -6 & -7 & -1 & 4 & -1 & 12 & -5 & 0 & 3 & 100 \\
\hline IT-Hardware & & 3 & -7 & 8 & -2 & -2 & 12 & -2 & -5 & -5 & 100 \\
\hline Media & & -15 & -11 & 14 & 0 & 25 & -10 & -3 & 0 & 0 & 100 \\
\hline Personal services & & 1 & -7 & 3 & 5 & 0 & -2 & -1 & 1 & 0 & 100 \\
\hline Professional services & & 4 & 3 & 2 & -1 & 2 & -10 & 2 & 0 & -1 & 100 \\
\hline Financial & & -15 & -6 & 43 & -1 & 0 & -8 & -7 & -3 & -3 & 100 \\
\hline Other services & & 1 & -6 & 7 & 0 & 11 & -1 & -5 & -2 & -5 & 100 \\
\hline TOTAL & & -1 & -61 & 120 & 27 & 53 & -11 & -38 & -24 & -64 & 100 \\
\hline Agriculture & \multirow{18}{*}{ 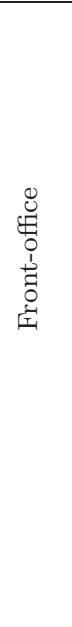 } & $\mathrm{n} / \mathrm{a}$ & $\mathrm{n} / \mathrm{a}$ & $\mathrm{n} / \mathrm{a}$ & $\mathrm{n} / \mathrm{a}$ & $\mathrm{n} / \mathrm{a}$ & $\mathrm{n} / \mathrm{a}$ & $\mathrm{n} / \mathrm{a}$ & $\mathrm{n} / \mathrm{a}$ & $\mathrm{n} / \mathrm{a}$ & 100 \\
\hline Mining and quarrying & & $\mathrm{n} / \mathrm{a}$ & $\mathrm{n} / \mathrm{a}$ & $\mathrm{n} / \mathrm{a}$ & $\mathrm{n} / \mathrm{a}$ & $\mathrm{n} / \mathrm{a}$ & $\mathrm{n} / \mathrm{a}$ & $\mathrm{n} / \mathrm{a}$ & $\mathrm{n} / \mathrm{a}$ & $\mathrm{n} / \mathrm{a}$ & 100 \\
\hline Manufacturing & & 3 & -3 & 4 & 3 & 0 & 0 & -3 & -2 & -1 & 100 \\
\hline Utilities & & -9 & 18 & -11 & -2 & -9 & -2 & 22 & 0 & -9 & 100 \\
\hline Construction & & 16 & -8 & -7 & 0 & 17 & -8 & -2 & -1 & -8 & 100 \\
\hline Retail & & 1 & -2 & 6 & 8 & -1 & -1 & -2 & -3 & -4 & 100 \\
\hline Wholesale & & -1 & -5 & 8 & -1 & 5 & 2 & 0 & -4 & -4 & 100 \\
\hline Transportation & & 8 & -8 & 6 & 9 & 5 & 0 & -4 & 0 & -15 & 100 \\
\hline Hotels-restaurants & & -2 & -3 & 6 & 8 & 3 & -1 & -1 & -4 & -4 & 100 \\
\hline Telecommunications & & -1 & -3 & 8 & 3 & 2 & -8 & 1 & -2 & -1 & 100 \\
\hline IT-Software & & -5 & -6 & -1 & 4 & -1 & 11 & -5 & 0 & 3 & 100 \\
\hline IT-Hardware & & 6 & -9 & 6 & -2 & -5 & 12 & -2 & -2 & -2 & 100 \\
\hline Media & & -12 & -9 & 13 & 0 & 25 & -5 & -8 & 0 & -3 & 100 \\
\hline Personal services & & -3 & -5 & 2 & 5 & 2 & -2 & -2 & 2 & 1 & 100 \\
\hline Professional services & & 1 & 3 & 2 & 1 & 2 & -11 & 2 & -1 & 1 & 100 \\
\hline Financial & & -13 & -5 & 41 & -2 & -1 & -8 & -7 & -2 & -3 & 100 \\
\hline Other services & & 5 & -7 & 7 & -2 & 12 & -3 & -4 & -3 & -4 & 100 \\
\hline TOTAL & & -8 & -53 & 89 & 32 & 54 & -25 & -15 & -22 & -54 & 100 \\
\hline
\end{tabular}


The examination of the sign predominance in each column and total differences (last row in Table 5) reveals substantial differences. Namely, Porto gave greater importance than Bucharest to factors such as customer and supplier accessibility ('plus' sign is predominant in the respective column, and total differences are significant). In turn, Bucharest gives greater importance than Porto to the ownership of facilities ('minus' sign prevails in the respective column), utilities and public services, representativeness of the area for the business, and low competition. Although competition is listed among the weakest factors in the matrix, the differences are notable (higher importance in Bucharest-Ilfov). Two of the industries (agriculture and mining) are not representative for metropolitan areas and were both represented by a small number of respondents in only one region (Bucharest-Ilfov), so the comparison against Porto is not applicable.

Horizontal analysis, industry by industry, exposes noteworthy differences in just a few sectors: utility supply, constructions, media, and financial services. As example, finance sector representatives in Porto consider customer accessibility as more important, while those in Bucharest favour affordable rent facilities. In addition, media sector behaviour in the study regions could indicate superior specialization and networking in case of Porto (see the need for accessibility to suppliers and customers) and, conversely, more vertical integration in case of Bucharest (see the need for larger space with proper utilities and services).

As far as micro-location preference matrices, the distinction between back-office and front-office was maintained. They are presented in Appendix 1 (by types of areas and industries) and Appendix 2 (by types of facilities and industries), for BucharestIlfov region. To note that industries with a more likely separation between the back-office and front-office are those represented by large size firms (as utilities, mining, telecommunication, transportation).

Large firms have the financial capacity for dedicated back-office facilities, and a growing need to demonstrate prestige; thus, they have such dedicated office facilities in well-known business parks.

In some areas, the vertical integration is a driver of the tendency to separate back-office and frontoffice.

In case of agriculture and retail, the tendency is for central storage. Telecommunication firms build their own retail networks.

In sectors such as manufacturing, wholesale, professional services, finance, IT-software, hotels \& restaurants, personal services, back-office and front- office activities usually share the same facility. In case of manufacturing, this behaviour contradicts the literature (explained by the general decline of the manufacturing sector in metropolitan areas, whereas the remaining production companies prefer small and peripheral sites).

Depending on the preferences for area and facility, some industries (in particular firms in manufacturing, wholesale, and transport industries) cluster in certain locations. A similar trend can be observed in case of other industries, such as retail, hospitality and personal services, clustering not for cooperation reasons, but to take advantage of the number of visitors from high streets, shopping centres, main thoroughfares and residential streets. Professional services and IT (software and hardware), is another group who prefer office buildings in business parks, in order to build their image on ultramodern facilities, required for attracting both customers and highly skilled employees.

\section{Further research development}

Built on the research findings, the research work aims to integrate the results in a geographical information system (GIS) that can be used for developing software tools able to assist entrepreneurs to find a proper location for their businesses.

A selected set of factors and indicators and data, corresponding to each location factor, is presented in Table 6 .

The selection is made according to the following criteria:

1. Quantifiable indicators and data;

2. Data availability - open data;

3. Possibility to integrate with GIS;

4. Transparency (easy to comprehend and friendly to use);

5. Synthetic - fewer sources, rich and targeted information.

In addition to the nine micro-location key factors, the legal constraints imposed by the General Urban Plan (GUP) must be observed. In case of Bucharest, there are four degrees of severity of legal restrictions:

- areas where all economic activity is excluded, except those established by the original planning (e.g. parks, infrastructure protection areas);

- areas and places where certain activities are banned (e.g. heavy industry, waste, restaurants and bars, gas stations);

- areas and places where some activities (automobile repair, retail) are restricted;

- areas assigned to land-uses according to GUP, where certain activities are encouraged and others discouraged. 
Management and Production Engineering Review

Table 6

Factors and indicators for GIS integration.

\begin{tabular}{l|l|l}
\hline Location factor & GIS factor & Indicator \\
\hline $\begin{array}{l}\text { 1. Large space availability } \\
\text { 2. Suitability of utilities/services }\end{array}$ & $\begin{array}{l}\text { Buy/Rent decision } \\
\text { Facility description }\end{array}$ & $\begin{array}{l}\text { Facility area - sq.m } \\
\text { Utilities, services } \\
\text { Safety } \\
\text { Type of area, facility }\end{array}$ \\
\hline $\begin{array}{l}\text { 3. Customer accessibility } \\
\text { 4. Supplier accessibility }\end{array}$ & Accessibility & $\begin{array}{l}\text { Road density } \\
\text { Parking lots } \\
\text { Public transportation }\end{array}$ \\
\hline 5. Number of potential visitors & Number of potential visitors & $\begin{array}{l}\text { Visibility } \\
\text { Aggregated indicator (traffic lights, sidewalks, } \\
\text { distance to the nearest shopping center, } \\
\text { high street) }\end{array}$ \\
\hline $\begin{array}{l}\text { 6. Affordable rent } \\
\text { 7. Facility ownership }\end{array}$ & $\begin{array}{l}\text { Price/sq.m } \\
\text { According to Buy/Rent decision }\end{array}$ \\
\hline 8. Representative area for the business & Positive externalities & $\begin{array}{l}\text { Clusters } \\
\text { Type of area }\end{array}$ \\
\hline 9. Low competition & Competition & Density of firms in the same industry \\
\hline 10. Legal restrictions & Urban zoning & Constraints, restrictions/conditioned activity \\
\hline
\end{tabular}

The proposed model is aimed for metropolitan areas which has several advantages for quick integration: pools of entrepreneurs, data availability. Fur- thermore, the model is extendable to a multi-regional or multi-country area. In this case, a new layer of macro-economic location factors should be added.

Appendix 1:

Matrix of the area type by industry (Bucharest-Ilfov) [weights \%].

Type of area

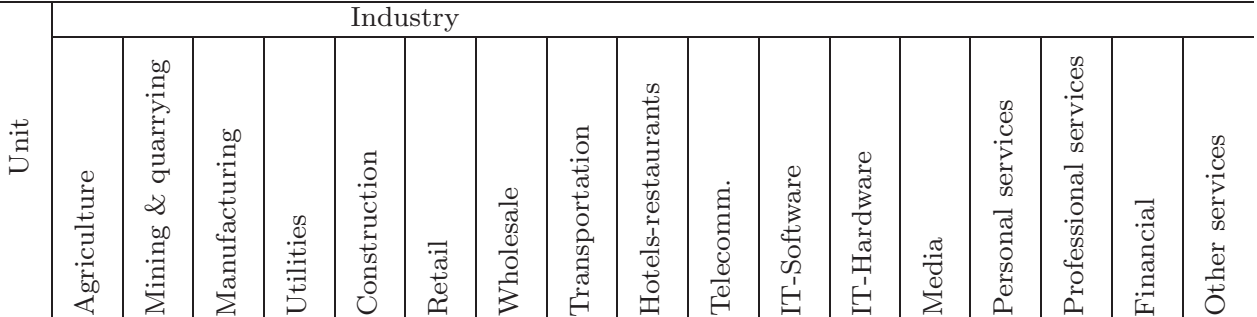

Industrial area

Wholesale park

Mixed park

Science \& Tech. park

Business park

Ring Road

Highway/access route

Shopping center

High street

Residential - main street

Residential - sec. street

Rural

Mobile unit

Virtual

Industrial area

Wholesale park

Mixed park

Science \& Tech. park

Business park

Ring Road

Highway/access route

Shopping center

High street

Residential - main street

Residential - sec. street

Rural

Mobile unit

Virtual

\begin{tabular}{|c|c|c|c|c|c|c|c|c|c|c|c|c|c|c|c|c|c|}
\hline \multirow{14}{*}{ 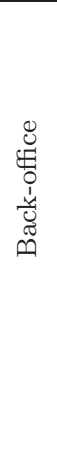 } & 31 & 0 & 21 & 17 & 18 & 2 & 0 & 14 & 9 & 0 & 2 & 0 & 0 & 0 & 20 & 0 & 6 \\
\hline & 44 & 43 & 10 & 11 & 9 & 12 & 36 & 32 & 0 & 0 & 0 & 0 & 15 & 0 & 0 & 0 & 4 \\
\hline & 0 & 29 & 24 & 25 & 0 & 5 & 8 & 0 & 9 & 4 & 0 & 10 & 0 & 0 & 0 & 0 & 2 \\
\hline & 0 & 0 & 3 & 0 & 0 & 0 & 0 & 0 & 9 & 11 & 12 & 10 & 0 & 0 & 0 & 4 & 6 \\
\hline & 0 & 29 & 3 & 14 & 21 & 11 & 4 & 14 & 20 & 35 & 40 & 31 & 69 & 43 & 30 & 72 & 34 \\
\hline & 0 & 0 & 10 & 11 & 0 & 5 & 23 & 14 & 0 & 4 & 0 & 0 & 0 & 0 & 0 & 0 & 4 \\
\hline & 0 & 0 & 10 & 11 & 0 & 2 & 0 & 0 & 0 & 4 & 2 & 0 & 0 & 0 & 17 & 0 & 2 \\
\hline & 0 & 0 & 3 & 0 & 0 & 11 & 0 & 0 & 0 & 4 & 0 & 0 & 0 & 0 & 0 & 0 & 2 \\
\hline & 0 & 0 & 3 & 0 & 0 & 16 & 4 & 0 & 0 & 16 & 5 & 10 & 0 & 0 & 6 & 0 & 2 \\
\hline & 0 & 0 & 3 & 11 & 5 & 7 & 4 & 0 & 53 & 11 & 19 & 0 & 15 & 11 & 28 & 24 & 17 \\
\hline & 0 & 0 & 3 & 0 & 25 & 13 & 0 & 0 & 0 & 4 & 18 & 21 & 0 & 35 & 0 & 0 & 10 \\
\hline & 25 & 0 & 3 & 0 & 12 & 11 & 20 & 0 & 0 & 0 & 0 & 0 & 0 & 0 & 0 & 0 & 8 \\
\hline & 0 & 0 & 0 & 0 & 9 & 4 & 0 & 25 & 0 & 8 & 2 & 18 & 0 & 11 & 0 & 0 & 4 \\
\hline & 0 & 0 & 0 & 0 & 0 & 0 & 0 & 0 & 0 & 0 & 0 & 0 & 0 & 0 & 0 & 0 & 0 \\
\hline \multirow{14}{*}{ 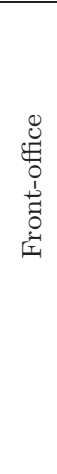 } & 31 & 0 & 23 & 17 & 11 & 0 & 0 & 0 & 8 & 0 & 2 & 0 & 0 & 0 & 25 & 0 & 7 \\
\hline & 44 & 43 & 11 & 0 & 14 & 3 & 38 & 38 & 0 & 0 & 0 & 0 & 0 & 0 & 5 & 0 & 2 \\
\hline & 0 & 0 & 24 & 14 & 0 & 6 & 13 & 0 & 0 & 10 & 2 & 10 & 0 & 0 & 0 & 0 & 0 \\
\hline & 0 & 0 & 0 & 0 & 0 & 0 & 0 & 0 & 8 & 9 & 11 & 21 & 0 & 0 & 0 & 0 & 2 \\
\hline & 0 & 29 & 15 & 14 & 15 & 4 & 0 & 17 & 0 & 36 & 43 & 31 & 60 & 39 & 28 & 74 & 36 \\
\hline & 0 & 0 & 6 & 11 & 0 & 6 & 17 & 0 & 0 & 0 & 0 & 0 & 0 & 0 & 0 & 0 & 2 \\
\hline & 0 & 0 & 10 & 11 & 0 & 4 & 0 & 0 & 0 & 0 & 2 & 0 & 0 & 0 & 16 & 0 & 2 \\
\hline & 0 & 0 & 0 & 0 & 0 & 23 & 0 & 0 & 18 & 4 & 0 & 0 & 0 & 0 & 0 & 0 & 5 \\
\hline & 0 & 0 & 11 & 0 & 0 & 18 & 6 & 17 & 0 & 14 & 6 & 0 & 0 & 0 & 0 & 0 & 3 \\
\hline & 0 & 29 & 0 & 22 & 11 & 13 & 13 & 0 & 57 & 13 & 13 & 0 & 13 & 10 & 21 & 26 & 14 \\
\hline & 25 & 0 & 0 & 0 & 30 & 6 & 0 & 0 & 0 & 0 & 18 & 21 & 13 & 32 & 0 & 0 & 14 \\
\hline & 0 & 0 & 0 & 0 & 5 & 9 & 13 & 0 & 0 & 0 & 0 & 0 & 0 & 0 & 0 & 0 & 7 \\
\hline & 0 & 0 & 0 & 11 & 14 & 3 & 0 & 0 & 0 & 4 & 2 & 18 & 0 & 10 & 0 & 0 & 5 \\
\hline & 0 & 0 & 0 & 0 & 0 & 5 & 0 & 29 & 8 & 9 & 2 & 0 & 13 & 10 & 5 & 0 & 0 \\
\hline
\end{tabular}


Appendix 2:

Matrix of the facility type by industry (Bucharest-Ilfov) [weights \%].

\begin{tabular}{|c|c|c|c|c|c|c|c|c|c|c|c|c|c|c|c|c|c|c|}
\hline \multirow[b]{2}{*}{ Type of area } & \multirow[b]{2}{*}{$\begin{array}{l}. \\
\vec{g} \\
5\end{array}$} & \multicolumn{17}{|c|}{ Industry } \\
\hline & & 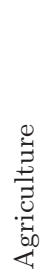 & 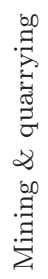 & 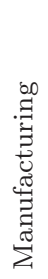 & 苟 & 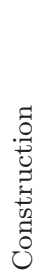 & 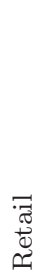 & 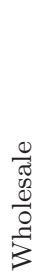 & 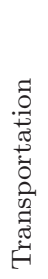 & 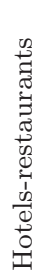 & 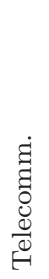 & 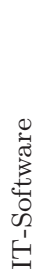 & 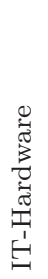 & 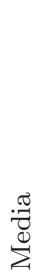 & 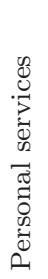 & $\begin{array}{l}0 \\
0 \\
0 \\
0 \\
0 \\
0 \\
0 \\
0 \\
0 \\
0 \\
0 \\
0 \\
0 \\
0 \\
0 \\
0\end{array}$ & 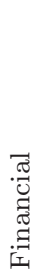 & 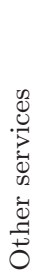 \\
\hline Open space/uncovered & \multirow{9}{*}{ 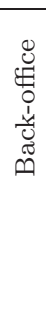 } & 31 & 0 & 21 & 17 & 18 & 2 & 0 & 14 & 9 & 0 & 2 & 0 & 0 & 0 & 20 & 0 & 6 \\
\hline Industrial building & & 44 & 43 & 10 & 11 & 9 & 12 & 36 & 32 & 0 & 0 & 0 & 0 & 15 & 0 & 0 & 0 & 4 \\
\hline Warehouse & & 0 & 29 & 24 & 25 & 0 & 5 & 8 & 0 & 9 & 4 & 0 & 10 & 0 & 0 & 0 & 0 & 2 \\
\hline Technical facility & & 0 & 0 & 3 & 0 & 0 & 0 & 0 & 0 & 9 & 11 & 12 & 10 & 0 & 0 & 0 & 4 & 6 \\
\hline Office building & & 0 & 29 & 3 & 14 & 21 & 11 & 4 & 14 & 20 & 35 & 40 & 31 & 69 & 43 & 30 & 72 & 34 \\
\hline Comm.space - individual & & 0 & 0 & 10 & 11 & 0 & 5 & 23 & 14 & 0 & 4 & 0 & 0 & 0 & 0 & 0 & 0 & 4 \\
\hline Comm. space - gallery & & 0 & 0 & 10 & 11 & 0 & 2 & 0 & 0 & 0 & 4 & 2 & 0 & 0 & 0 & 17 & 0 & 2 \\
\hline Villa & & 0 & 0 & 3 & 0 & 0 & 11 & 0 & 0 & 0 & 4 & 0 & 0 & 0 & 0 & 0 & 0 & 2 \\
\hline Apartment/house & & 0 & 0 & 3 & 0 & 0 & 16 & 4 & 0 & 0 & 16 & 5 & 10 & 0 & 0 & 6 & 0 & 2 \\
\hline Open space/uncovered & \multirow{9}{*}{ 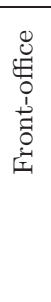 } & 31 & 0 & 23 & 17 & 11 & 0 & 0 & 0 & 8 & 0 & 2 & 0 & 0 & 0 & 25 & 0 & 7 \\
\hline Industrial building & & 44 & 43 & 11 & 0 & 14 & 3 & 38 & 38 & 0 & 0 & 0 & 0 & 0 & 0 & 5 & 0 & 2 \\
\hline Warehouse & & 0 & 0 & 24 & 14 & 0 & 6 & 13 & 0 & 0 & 10 & 2 & 10 & 0 & 0 & 0 & 0 & 0 \\
\hline Technical facility & & 0 & 0 & 0 & 0 & 0 & 0 & 0 & 0 & 8 & 9 & 11 & 21 & 0 & 0 & 0 & 0 & 2 \\
\hline Office building & & 0 & 29 & 15 & 14 & 15 & 4 & 0 & 17 & 0 & 36 & 43 & 31 & 60 & 39 & 28 & 74 & 36 \\
\hline Comm.space - individual & & 0 & 0 & 6 & 11 & 0 & 6 & 17 & 0 & 0 & 0 & 0 & 0 & 0 & 0 & 0 & 0 & 2 \\
\hline Comm. space - gallery & & 0 & 0 & 10 & 11 & 0 & 4 & 0 & 0 & 0 & 0 & 2 & 0 & 0 & 0 & 16 & 0 & 2 \\
\hline Villa & & 0 & 0 & 0 & 0 & 0 & 23 & 0 & 0 & 18 & 4 & 0 & 0 & 0 & 0 & 0 & 0 & 5 \\
\hline Apartment/house & & 0 & 0 & 11 & 0 & 0 & 18 & 6 & 17 & 0 & 14 & 6 & 0 & 0 & 0 & 0 & 0 & 3 \\
\hline
\end{tabular}

\section{$\underline{\text { References }}$}

[1] Thünen J.H.V., von Thunen's Isolated State (English translation of Der Isolierte Staat in Beziehung auf Landwirtschaft und Nationalökonomie by Carla M. Wartenberg, London: Pergamon Press, 1966), Stuttgart: Gustav Fischer, 1826.

[2] Alonso W., Location and Land Use: Towards a General Theory of Land Rent, Cambridge, Massachusetts: Harvard University Press, 1964.

[3] Weber A., On the Location of Industries (English translation of Über den Standort der Industrie by Carl Friedrich, Chicago: University of Chicago Press, 1929), Tübingen: Mohr, 1909.

[4] Christaller W., Central Places in Southern Germany, (partial English translation of Die zentralen Orte in Süddeutschland by Charlisle W. Baskin, Prentice Hall 1966), Jena: Gustav Fischer, 1933.

[5] Lösch A., The Economics of Location (English translation of Die räumliche Ordnung der Wirtschaft by William H. Woglom, New Haven: Yale University Press, 1954), Jena: Gustav Fischer, 1940.

[6] Hotelling H., Stability in Competition, Economic Journal, 39, 41-57, 1940.
[7] Pred A., Behavior and location: Foundations for a geographic and dynamic location theory, 1, Lund: Gleerups Forlag, 1967.

[8] Krumme G., Toward a Geography of Enterprise, Economic Geography, 45, 1, 30-40, 1969.

[9] Porter M., On Competition, Clusters and Competition: New Agendas for Companies, Governments, and Institutions, A Harvard Business Review Book, 197-288, 1998.

[10] Putnam R.D., The prosperous community: social capital and public life, The American Prospect, 4, 13, 35-42, 1993.

[11] Marshall A., Principles of Economics, chap. X (Revised Edition), London: Macmillan; reprinted by Prometheus Books, 1920.

[12] Boschma R.A., Lambooy J.G., Evolutionary economics and economic geography, Journal of Evolutionary Economics, Springer, 9, 4, 411-429, 1999.

[13] Fujita M., Krugman P.R., Venables A.J., The Spatial Economy: Cities, Regions and International Trade, Cambridge, Mass.: MIT Press, 1999.

[14] Arthur B.W., Increasing Returns and the Two Worlds of Business, Harvard Business Review, 74, 4, 100-109, 1996. 
[15] Pellenbarg P., Wissen L.V., Dijk J.V., Firm relocation: state of the art and research prospects, Research Report 02D31, University of Groningen, Research Institute SOM (Systems, Organisations and Management), 2002.

[16] Reijmer I., van Noort E., Location choice of SMEs, Zoetermeer: Scales Research Reports B199804, EIM Business and Policy Research, 1999.
[17] Mariotti I., Firm relocation and regional policy. A focus on Italy, the Netherlands and the United Kingdom, Utrecht/Groningen: Royal Dutch Geographical Society/Department of Spatial Sciences University of Groningen, 2005.

[18] Ghita C., Scarlat C., Business location behaviour in time of economic crisis: case of Romania, in Conference proceedings: Advances in Business-Related Scientific Research Conference, Koper, Edukator, 2012. 